\title{
Cosmic Spiritualism among the Pythagoreans, Stoics, Jews and Early Christians
}

Phillip Sidney Horky

\section{I3.I Introduction}

It is a curious feature of human reasoning that it enjoys the use of analogies in order to explain the inexplicable: in Ancient Greece, from Homer onward we are constantly confronted with, for example, gods in human form, with human attributes that are often pushed to extremes. ${ }^{\text {I }}$ Something striking, however, happened in the late sixth century BCE: Greek intellectuals began to criticise this representation of the gods and, by extension, the parts of the kosmos that the gods either were thought to embody $^{2}$ or to which they were thought to be assigned governance. ${ }^{3}$ Instead, a new sort of 'god' arrived on the scene, one differentiated by its lack of human features, while at the same time being marked by its perfection and comprehension. Xenophanes of Colophon called this god 'Intellect' or 'Mind' (Nous), retaining the most positive attribute of the most authoritative gods in the Greek (Zeus) and Indo-Iranian (Ahura Mazda) pantheons. ${ }^{4}$ This move would be decisive historically: for centuries - well into the second century CE - philosophers like Anaxagoras, Diogenes of Apollonia, Plato, the Early Platonists, and the Stoics would follow Xenophanes in positing an intelligent god, and extend his creative activities beyond himself in the act of cosmogony. ${ }^{5}$ The first material object constructed by this intelligent god was the kosmos, the all-encompassing

\footnotetext{
I The classic work on analogy in ancient Greece remains Lloyd 1966, especially pp. 192-209.

${ }^{2}$ As in the case of Mesopotamian and Orphic cosmogonies. For an excellent general discussion, see Burkert 2008.

${ }^{3}$ As in the case of Homeric and Hesiodic theogonies.

${ }^{4}$ Xenophanes DK 2I B IO-26. Generally, on the distinctiveness of Xenophanes' Nous, see Benzi 2016. On the usually unremarked interrelationships between Greek philosophy and Zoroastrian theology, see Horky 2009.

5 Anaxagoras DK 59 B I3; Diogenes of Apollonia DK 64 B 4-5; Pl. Phlb. $30 d$ and Ti. 39d; for the Early Platonists, see Speusippus Frs. 89-9I IP; Xenocrates Fr. 133 IP²; for the Stoics, see L\&S 46 A-B.
} 
universe that was, one way or another, ordered and differentiated. ${ }^{6}$ Similarly, in Hebrew traditions that are roughly contemporary, accounts of the generation of the universe and all its parts arise, and in the text of Genesis we see Yahweh as a primal cultivator, differentiating the parts of the kosmos, fashioning the manifold creatures to inhabit it, and assigning the human being the task of terrestrial oversight. ${ }^{7}$ The adaptation of Hebrew traditions in the writings of early Christianity, starting from the latter part of the first century CE, sees the birth of a new spiritual cosmology, a celebration of the 'last' Adam and son of God who is to inherit the kingdom of heaven in the promise of apocalyptic fulfilment suggested by some of the more prophetic works of the Hebrew Bible.

It is agreed that $\pi v \varepsilon \tilde{u} \mu \alpha$, which normally translates as 'breath' but eventually comes to mean 'spirit' in a marked sense, plays a fundamental role in the latter tradition, marking the filial inheritance of early Christianity from Judaism and setting out a new path of spiritual cosmology - a return of Man to the paternal source that had originally bestowed upon him life. ${ }^{8}$ What is not often noted, however, is that much of the pneumatic theology that is found in the New Testament, which would come to exercise a tremendous effect on the world after Christianity's triumph in the Late Roman Empire, shows remarkable inheritances also from the secularising, scientific tradition of the Greek philosophical cosmology. For, as I will argue in this chapter, it is with Paul that we see not only the bridging of the Hebrew and Indo-European traditions of cosmogonic and anthropogonic pneumatics - that had already been anticipated by his predecessor Philo of Alexandria, a Hellenic Jew who was additionally a Platonist/Stoic philosopher - but also a subsuming of the scientific tradition under a notion of divine pneumatics that has an active role in religious teaching, understanding and even prophetics. Analogies with earlier pagan usages will be retained, but they will also be adapted to new and emergent spiritual concerns that eventually brought the Christian community together - the natural and logical extension of what the Stoics had thought was the primary ontological and natural function of 'breath'. Hence, I will approach the topic of cosmic spiritualism by tracing the history of the pneumatic cosmogony/anthropogony analogy, from its earliest expression in the lost works of the Pythagoreans, through the Stoics who adapted and modified it, including the deeply influential Posidonius

\footnotetext{
${ }^{6}$ See e.g. Anaxagoras DK 59 B I2-I3; Diogenes of Apollonia DK 64 B 2-3; Pl. Ti. 3IC-32a.

7 Genesis I:I-3I.

${ }^{8}$ It is important to note from the beginning that the word for 'breath' and 'spirit' is the same in Greek: $\pi v \varepsilon \tilde{u} \mu \alpha$. 'Breath' originates in Old English as brœð, and 'spirit' is an Anglicisation of Latin spiritus.
} 
of Apamea and the remarkable and understudied Jewish philosopher Philo of Alexandria, to the texts of the New Testament, especially the creative re-imaginings of Paul. ${ }^{9}$

\subsection{Origins of Cosmic Breathing: The Pythagoreans}

Perhaps the very earliest evidence in the Western world of 'breath/spirit' (Greek $\pi v \varepsilon \tilde{u} \mu \alpha$ ) occupying a formative place in both cosmic and human generation is associated with the enigmatic philosopher Pythagoras of Samos, who died in the first few decades of the fifth century в се. ${ }^{\text {IO }}$ The evidence is, as is often the case with ancient philosophers who left no writings, late and subject to bias, but it nevertheless gives us a good starting point for our analysis of breath in the Hellenistic and Post-Hellenistic worlds, and beyond. Our materials come from Aristotle's lost text $O n$ the Philosophy of Pythagoras, probably written in the mid fourth century в СЕ, and it is as potent as it is enigmatic (a common problem for evidence regarding early Pythagoreanism). But it is confirmed and expanded by two other pieces of evidence, the first from Aristotle's Physics itself, and the second given by Simplicius in his much later commentary on that text:

A. In the first book of On the Philosophy of Pythagoras, he [Aristotle] writes that heaven is one, and that time and breath, i.e. void, which differentiates the spaces of each thing in each case, was drawn in from the infinite; for there is a fiery place on the inside.

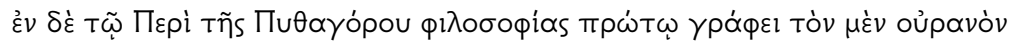

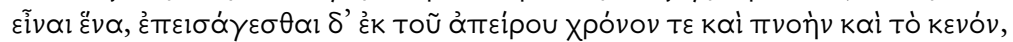

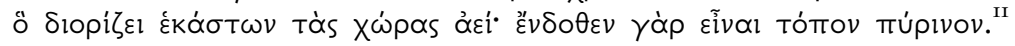
(Stobaeus, Eclogues I.I8.I c = Aristotle, Fr. 20I Rose ${ }^{3}=$ DK 58 B 30; tr. after Bernabé and Mendoza)

B. The Pythagoreans, too, held that void exists and that it enters the heaven from the infinite breath, the kosmos inhaling also the void which distinguishes the natures of things as if it were what separates and distinguishes the terms of a series.

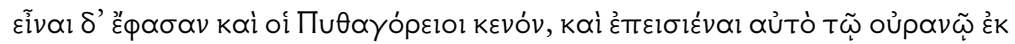

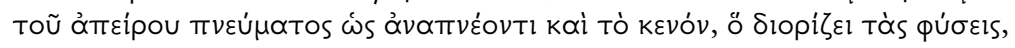

9 For a useful general study of Paul's relationship to Jewish and Hellenistic (including Stoic and Platonist) wisdom, see especially Alexander 200 .

Io The most informative paper I have read on this subject remains Malcolm Schofield's 'Pythagoras the Plagiarist' (n.d.).

II Text from Primavesi 2018. 


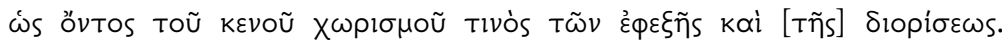
(Aristotle, Physics 4.6.213b22-6; tr. after Hardie and Gaye)

C. They [the Pythagoreans] used to say that the void penetrates the kosmos, as if the latter inhaled it or exhaled it like a breath of what is diffused around it from the outside.

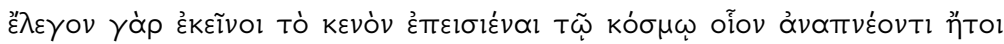

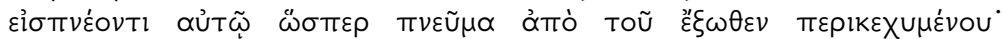
(Simplicius, Commentary on Aristotle's Physics p. 65I.39-4I Diels; tr. after Bernabé and Mendoza)

Hence, we see the ultimate beginnings of a mode that employs biological analogy to the purpose of explaining nothing less than the constitution of the entire well-ordered universe. This theory could be thought to set in motion what would, inevitably and after much mathematical speculation, lead to the modern concept of the oscillating expansion and retraction of the universe, often associated with the oscillating universe version of the 'big bang'. For the early Pythagoreans, the universe is understood to function, to live, as an animal - once it has been constituted and its parts set into motion, it inhales and exhales 'breath' from the infinity that surrounds it (perhaps explaining, by analogy, the expansion and contraction of the ordered universe), and from which it differentiates itself and its individual natures. ${ }^{\mathrm{I2}}$ The vehicle for this differentiation is void, or the space that is occupied by matter, and that is like 'breath' ${ }^{13}$ The push and pull that demonstrates the universe's capacity for breathing in the void which (now) articulated matter occupies as the universe takes form. ${ }^{\mathrm{I}}{ }^{4}$ The sign that the universe and its constituents are properly differentiated from what is chaotic and disorderly is the persistent motion indicated by regular respiration.

It had been common to anthropomorphise the gods among the Greeks, assuming that Zeus and Hera, Apollo and Athena, were sort of 'super-

I2 Aristotle probably means 'natures' here in the sense of 'substances'.

${ }^{13}$ Even if the concept of the void was an invention of the Eleatics, as Schofield (n.d.) hypothesises, the evidence could certainly be taken to refer to early Pythagorean philosophy in the wake of challenges brought by Parmenides' and Zeno's philosophy. For a similar approach to Pythagoreanism in the two generations after Pythagoras' death, see Horky 2013: I3I-49.

${ }^{14}$ Beyond this very general description (which no doubt some will find anachronistic), it is unfortunately impossible from this information to deduce exactly what sort of 'void' is implied here. Did the Pythagoreans conceive of this void as absolute space, or as relative spaces between parts of the kosmos? Or is it possible that the Pythagoreans conceived of void as both absolute space (within which matter as a whole is situated) and the relative spaces between the parts of the kosmos after cosmogony? I am inclined towards the latter view, but this could be impossible to adjudicate, given the challenges with establishing the Aristotelian source text. For further thoughts, see Primavesi 20I8: I22-25. 
humans' who, while they did not of course die, nevertheless had the physical and especially emotional attributes of human beings, usually to extreme levels. Hence, we see that the Homeric gods breathe: in particular, they 'breathe into' humans certain insights - their breathing is a kind of divine gift or guidance, not at all indicative of their mortality, but rather the mark of their immortality. ${ }^{\text {Is }}$ This is of course not unlike what we see in the Hebrew Scriptures, especially the famous creation of the first human in Genesis 2.7, or its expansion in the Gospels in the New Testament, both of which we will discuss later on. But with the advent of Pythagorean philosophy in Greece ${ }^{16}$ something had changed: the kosmos itself, understood in speculatively biomorphic terms, was now being associated with a unified, living being, whose self-constitution was regulated through its primal activity of breathing. The effect was immediate. Charles Kahn has argued that Xenophanes, whom we mentioned earlier, went so far as to reject a Pythagorean notion of cosmic respiration in his description of the god Mind. ${ }^{17}$ Not much later, Empedocles, who was associated with the Pythagoreans by Hellenistic historiographers, ${ }^{18}$ speculated about the workings of animal respiration, comparing it with the motion of clepsydra; this is not necessarily the same thing as cosmic breathing - the Pythagorean analogy is biomorphic, and the Empedoclean mechanical - but the analogy is nonetheless said to apply to all things in Empedocles' universe. ${ }^{\text {I9 }}$ Indeed, the growth and expansion of the kosmos is analogous to what happens in animal birth about a generation later, in the writings of the mathematical Pythagorean Philolaus of Croton (fl. 420s-IOS BCE), who, according to Aristotle's student Meno, observed:

Immediately after birth, the animal breathes in the external air, which is cold. Then it sends it out again like a debt. Indeed, it is for this reason that there is desire for external air, so that our bodies, which were too hot before, by the drawing in of breath from the outside, are cooled thereby.

is E.g. Hom. Od. 19.138.

I6 Bernabé and Mendoza (2013) demonstrate the close connections between this Pythagorean account of the cosmogony and that of the Rig Veda.

17 Kahn 200I: 36, by reference to DK 2I AI.19 = D.L. 9.19.

I8 Empedocles' relationship with Pythagoreanism remains difficult to pin down, although he was associated with the Pythagorean pretenders by Neanthes of Cyzicus (FGrHist 84 F $26=$ D.L. 8.55) and Timaeus of Tauromenium (FGrHist 566 F I4 = D.L. 8.54). For Empedocles as 'democratising' Pythagorean, see Horky 2013: II6-I9 and especially 2016.

I9 The fragment literally claims that 'all things' ( $\pi \alpha \dot{\alpha} \nu \alpha)$ respire the way Empedocles describes (DK $3 \mathrm{I}$ B Iоo), but it is Aëtius ( $\mathrm{DK}_{3 \mathrm{I}} \mathrm{A}_{74}$ ) who interprets this as referring to the first animal. Generally, on this material, see Lloyd 1966: 328-33. 


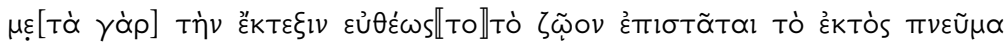

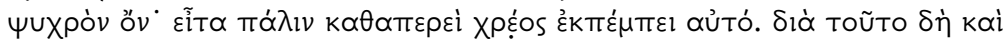

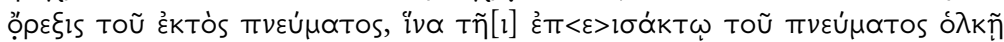

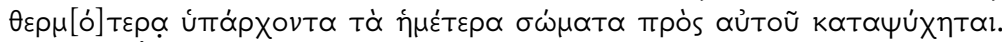
(Philolaus of Croton DK 44 A 27 ; tr. by Huffman)

That animal breathing expressed the intelligence, and the intelligibility, of the universe was suggested by Diogenes of Apollonia, who found in

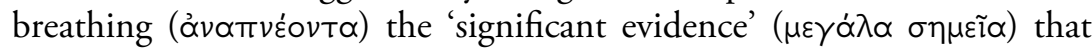
both humans and other animals possessed intelligence (vónols). ${ }^{20}$ Such an analogy would take hold in remarkable ways throughout antiquity, informing many accounts that sought to combine the scientific with the ethical, the philosophical with the spiritual.

\section{I3.3 Breath as Sustaining Power: The Stoics and Posidonius of Apamea}

The Pythagoreans' pneumatic cosmogony was generally ignored by fourth-century В СЕ philosophers, perhaps due to the authoritative cosmogonic visions that were presented by Plato and Aristotle. ${ }^{2 \mathrm{I}}$ There is some indication that Aristotle's student, Theophrastus, identified God with both the heavens and breath, but it is unclear how this association is supposed to be understood. ${ }^{22}$ Moreover, due to scarcity of evidence, it is difficult to know whether the Pythagorean model offered traction to the early Stoics of the late fourth and third centuries BCE, but there are some suggestions that it did. It was adopted by the remarkable secondcentury BCE philosopher Posidonius of Apamea, whose investigations into nature reflected a particular declension of Stoicism: ${ }^{23}$

The kosmos, they ${ }^{24}$ say, is one and this is limited, having a spherical shape; for a shape of this sort is most suitable for motion, according to Posidonius in the fifth book of his Natural Reason and the followers of Antipater in their

${ }^{20}$ DK 64 B 4 .

${ }^{21}$ Plato expressly rejected the notion that the World-Soul breathed or practised physical activities analogous to human life (Ti.33CI-34a7), on which see Broadie 20I2: 92-94. For further discussion of Plato and Aristotle, see the contributions by Brisson, Johnson, Gagné, and Boys-Stones (Chapters 6, 4,9 and 5 , respectively).

${ }^{22}$ Clem. Protr. 5.66.5 = Theophrastus F 252B FHS\&G: 'And that man from Eresus, Theophrastus, the associate of Aristotle, supposes in one place that God is heaven (oủpavóv), and in another that He is breath ( $\pi v \varepsilon \tilde{\mu} \mu \alpha)^{\prime}$.

${ }^{23}$ The quotation also mentions the 'followers of Antipater', but Posidonius' fifth book of his Natural Reason is expressly cited.

${ }^{24}$ The Stoics are intended here. 
works On the Kosmos. Outside this [sc. the kosmos] is diffused the unlimited void, which is incorporeal. By 'incorporeal' they mean that which, although it is capable of being occupied by corporeal things, is not occupied by them. There is no void in the kosmos, but it is wholly unified. For this [sc. unification] necessarily results from reciprocal breathing and tension of

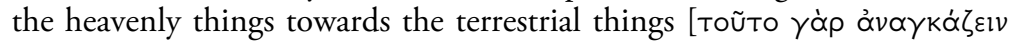

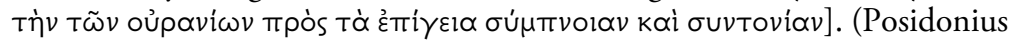
of Apamea Fr. 8 Kidd = Diogenes Laertius 7.I40)

Posidonius adapts the Pythagorean cosmogony to a Stoic framework, elaborating a more complex theory of corporeals (i.e. bodies, or threedimensional material objects) and incorporeals (i.e. empty space) according to the principle of potentiality: void is incorporeal, i.e. a space that could be occupied by corporeals, but currently is not. Void as such does not exist in the kosmos, but rather the persistent 'reciprocal breathing'

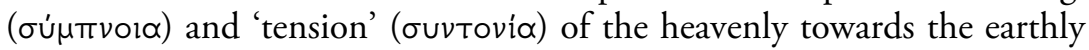
things indicates that all space within the ordered universe is, at all times, occupied by corporeal matter. Importantly, for Posidonius, as for earlier Stoics, the soul is defined as a 'hot breath' ( $\pi \nu \varepsilon \tilde{u} \mu \alpha$ है $v \theta \varepsilon \rho \mu \circ v)$ and is matter, and it is soul that is said to 'hold together' bodies, 'just as glue controls both itself and what is outside' (

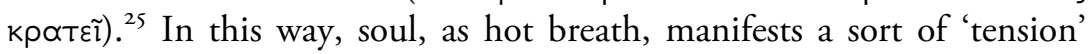
between things that brings coherence and cohesion between what is internal and what is external: ${ }^{26}$ in this cosmic situation, the external is what is on the heavenly 'outside' or the edge of the ordered universe, and the internal is what is circumscribed under it. It is doubtful, however, that Posidonius understood the 'outside' to be in the infinite void beyond the heavenly outer rim of the universe, as the Pythagoreans did. ${ }^{27}$ Perhaps at this point it is worth pointing out that, for Posidonius, the kosmos was defined as the 'systematic compound composed out of heaven, earth, and

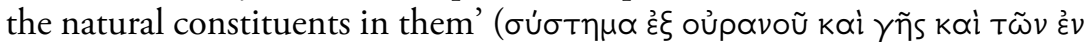

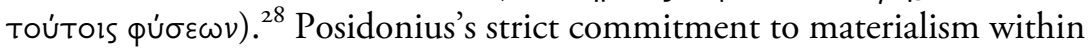
the ordered universe reveals itself in the claim that soul, as hot breath, is

${ }^{25}$ Fr. 149 Kidd. For an excellent general discussion of Stoic pneuma and its antecedents in Hellenistic medicine, see Hankinson 2002: 298-30I.

${ }^{26}$ For the Stoics, heat and cold are 'active' powers, whereas earth and water are 'passive' elements (cf. Nemesius p. 164.I5-18 Matthaei $=$ L\&S 47 D).

27 Here Posidonius follows Plato, who, contrary to the Pythagoreans, claims that the kosmos, as a perfect sphere, did not breathe in the outside air (Ti. 33c).

${ }^{28}$ Fr. I4 Kidd. Note that a second definition is also added that explains the first: 'a systematic compound composed out of gods, men, and what has come into being for their sake'. Compare these definitions with that of ps-Aristotle, On the Kosmos 39rb9-I2, and Chrysippus (SVF 2.527.I-3 = Arius Didymus Fr. 3I), both discussed by Johnson in Chapter 4. 
qualified matter, unlike the breath of the Pythagorean cosmogony, which was immaterial and described even as the void. ${ }^{29}$ Indeed, someone might object that it would be absurd if 'void', i.e. the dimensions of external 'space', were to 'insert itself into or 'penetrate' matter, as the Pythagoreans held in their biomorphic model of cosmology. ${ }^{30}$

Posidonius' account of breath as 'tension' taps firmly into Stoic orthodoxy. For 'breath', as we saw, is the rarified matter or stuff that, when qualified as 'hot', ${ }^{3 \mathrm{I}}$ actively constitutes soul, which itself makes sure that bodies remain unified as such (and identifiable as what-they-are). Or, another way to put it, 'breath' sustains animate corporeal objects-as-such. ${ }^{32}$ What, then, does Posidonius mean by the rarified stuff or matter that is 'breath'? Here we see a fascinating, if challenging, pair of Stoic notions

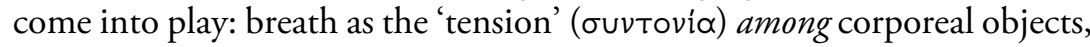
or as the 'tenor' (tóvos or "̇ $\xi 15$ ) within them. ${ }^{33}$ 'Tension' could be understood as the means by which diverse objects are able to interact successfully. It is fundamental, as we saw earlier with Posidonius, for the sustenance of the universe as an orderly composition of divine and mortal elements that belong in it. The metaphor employed by the Stoics for this aspect of 'breath' is both musical and biological: in Aristotle, it refers to the kinds of harmonic concords that are high-pitched, ${ }^{34}$ but it is not a simple metaphor for psychic or political 'harmony'. ${ }^{35}$ Of more relevance to our study of the Stoics, in the case of biology, Aristotle uses 'tension' (ouvtovia) to describe the quality of the sinews that connect the parts of animal bodies. In animals at their prime, the joints and sinews are more tense, whereas both prior and posterior to that age, they are more slack. ${ }^{36}$

29 As Long helpfully puts it (1996: 227), 'The Stoics had reasons ... for insisting that the soul is corporeal; but those reasons fall within a general conceptual framework which denies that anything can exist which is not a body or a state of a body'.

3o Compare again Plato's rejection of the presence of void inside the animate being in his discussion of breathing (Ti. $79 \mathrm{~b}-\mathrm{c})$.

${ }^{31}$ Galen testifies that the breath which constitutes the soul's commanding faculty possesses two elements/qualities, which are 'air and fire'/'cold and hot' (L\&S $47 \mathrm{H})$.

32 See e.g. Galen's description of the physics involved (L\&S $47 \mathrm{~F}$ ): 'The chief proponents of the

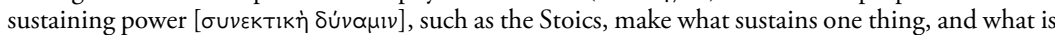

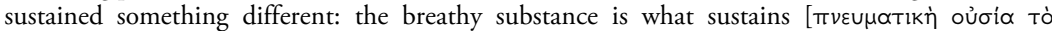

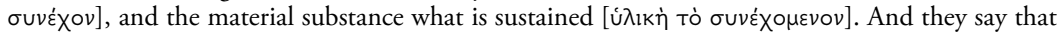
air and fire sustain, and earth and water are sustained.'

33 The terminology is inconsistent and depends on whether the evidence base is original to a Stoic or a critic. For example, Chrysippus himself probably used $\check{\varepsilon} \xi 15$, whereas the same concept appears to have been reinterpreted by later authors as tóvos.

34 Arist. Pol. 8.7.134Ib36-4I.

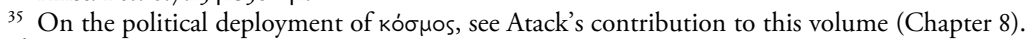

${ }^{36}$ Arist. GA 5.7.787b6-19. 
Hence, so Aristotle argues, animals in their prime, when their sinews and joints are most 'tense', are strongest, and he gives as evidence for this mature bulls, who, according to him, have particularly sinewy hearts, which, thanks to the high tension in their flesh, produce the tense breathing that one observes when a bull breathes. ${ }^{37}$ 'Tension' thus understood appears to be a force that marks the optimal physical conditions for systemwide performance, and hence it is no surprise that Posidonius, as a committed teleologist, adapted Aristotle's biological usage to his pneumatic cosmology.

The evidence for Stoic breath as internal 'tenor' (tóvos or "̌́lऽ) is more substantial, but also more variegated and complex. First, we should consider the relationship between 'tension' and 'tenor', before going on to describe how 'tenor' was thought by the Stoics to be a species of the genus 'breath'. Now the best evidence for the relationship between external 'tension' and internal 'tenor' comes from the Christian bishop and philosopher Nemesius of Emesa, who flourished in the fourth century CE:

Now if the soul is a body of any kind at all, even if it is of the rarest consistency, what is it that sustains it [sc. the soul]? For it has been proved that every body needs something to sustain it, which is an endless regress until we reach something incorporeal. If they should say, as the Stoics do,

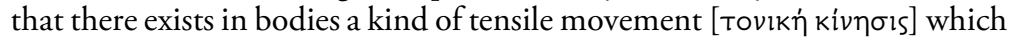
moves simultaneously inwards and outwards, the outward movement producing quantities and qualities, and the inward one unity and substance, we must ask them (since every movement issues from some power), what this power is and in what substance it consists. (Nemesius, On Human Nature pp. 70.6-7I.4 Matthaei = Long \& Sedley $47 \mathrm{~J}$; tr. by Long and Sedley)

As Long and Sedley note in their commentary on this passage, 'this is the most precise surviving testimony concerning the internal effects of $\pi v \varepsilon \tilde{u} \mu \alpha$ within a compound body'. ${ }^{8}$ We should add that it is also the most precise surviving testimony on the relationship between 'tension' and 'tenor'. As we saw earlier, 'tension' occurs between bodies within a complex 'system', whereas 'tenor' is within an individual body as such. How do these relate? We can only conjecture, but Nemesius's passage gives us some grounds to do so. 'Tensile movement' goes both outwards and inwards: the outwards breathing of, say, an animal is the power that

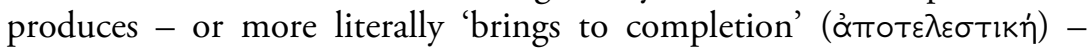
qualities and quantities, which we can perceive in one another: hence, we might say that Aristotle's bull is 'swollen with anger' when we

37 Ibid. $\quad{ }^{38}$ L\&S vol. II, p. 282. 
perceive the bull's exhalation..$^{39}$ Contrariwise, the inwards breathing of an animal is what guarantees its unity, its identifiability as an individual substantial body - this animal; ${ }^{40}$ in the absence of breath, the individual substance no longer exists, and this is the animal's 'death'. ${ }^{4 \mathrm{I}}$ After the matador has delivered the final blow, the bull, who cannot inhale breath because he has respired, ceases to be Aristotle's bull as such: he is no longer, from a metaphysical and epistemological point of view, identifiable as this individual bull, and the failure to inhale indicates the beginning of the partition of the bull's physical body into (what will eventually become) an infinite number of material parts or pieces. The same could be said, we would imagine, of all individual compound animate substances, whether they are animals of lower epistemic and aretaic capacities such as Aristotle's bull, or sages who possess full rational capacities, like Socrates.

What about individual simple substances within the broader physical world, such as 'this rock' or 'this piece of iron'? While they are, from our perspective, 'inanimate', i.e. they lack soul, the Stoics were so deeply committed to their comprehensive pneumatic cosmology that they believed objects such as 'this rock' and 'this piece of iron' to - in some qualified sense - 'breathe'. This makes some sense, at least in accordance with the Stoics' unique conceptualisation of internal breathing as 'tenor', i.e. the breathing that guarantees an individual corporeal object's existence as such. On the subject of their 'innate breath', Galen provides us with further evidence of division of the genus 'breath' into several species: 'physical' or 'natural' (тò quбıxóv) breath, 'animate' (тò quXıkóv) breath,

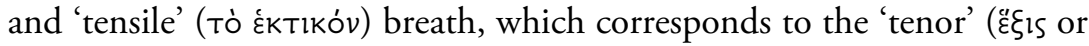
Tóvos) we just discussed:

There are two kinds of innate breath, the physical kind [тò фuбıкóv] and the animate kind [тò $\psi u \mathbf{u} ı$ ikóv]. Some people [sc. the Stoics] also posit a third, the tenor kind [тò घ́kTikóv]. The breath which sustains stones is of the tenor kind, the one which nurtures animals and plants the physical, and the animate breath is that which, in animate beings, makes animals capable of

39 If this is indeed how to read the reference to 'quality and quantity', the former of which is literally

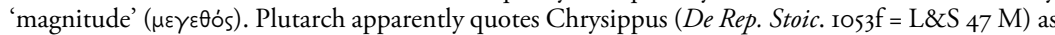
claiming that tenors are 'currents of air' which sustain bodies, and that specific essential qualities in simple bodies are owed to the power of the sustaining currents of air, e.g. hardness in iron, density in stone and whiteness in silver. What Chrysippus would have said about complex or compound bodies like animals is unclear and must remain conjectural. See Long 1996: 230.

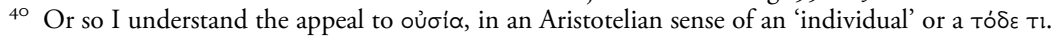

${ }^{41}$ Again, a reformulation of ideas already present in Plato's Timaeus (78e). 
sensation and of moving in every way. (Galen, Medical Introduction I4, p. 726.7-II Kühn = Long \& Sedley 47 N; tr. after Long \& Sedley)

As is common in their natural philosophy, the Stoics differentiate species of internal 'breath' as peculiar to objects within nature according to a hierarchy: all objects share of, or participate in, the cosmic kind of internal 'breath', i.e. the 'tenor' that not only unifies the entire kosmos and all the parts that belong to it, but also the 'tenor' that individualises complex and simple bodies, such as wise animals like Socrates of Athens or the Kosmos; animals that cannot achieve virtue and wisdom such as Aristotle's bull; plants such as this rose; and metals and stones like this piece of iron. At a higher level, the species of 'breath' that provides nutrition for growth is reserved from wise animals, unwise animals and plants, is 'physical' or 'natural'; stones and metals do not possess it. One step up is the kind of breath that animate objects, wise or unwise, possess: Galen calls it 'animate', or related to 'soul' traditionally understood as lifeforce that is manifest through sense perception. Galen does not explain here what sort of 'breath' is unique to wise animals such as Socrates and the Kosmos, ${ }^{42}$ although the passage implies that there is more to the story than what he is telling.

In order to pursue this line of thought, we now need to turn to another philosopher with strong Platonist and Stoic commitments, in concert with a remarkably deep commitment to his Jewish faith: Philo of Alexandria, a philosopher who was probably writing about 125 years after the other Stoic we have been discussing so far, Posidonius. We are now firmly in what is often called the Post-Hellenistic intellectual world, where the destruction of the philosophical schools in Athens in the 80s BCE (the Academy and the Lyceum) was offset by the increased production of philosophical texts circulating throughout the Mediterranean. The effect of these changes was a brilliant and enigmatic kind of eclecticism. In the Post-Hellenistic world, pagan philosophy and Semitic religions coexist and inform one another without any obvious contradiction. As we will see in the case of Philo, pagan philosophy provides the explanatory models for biblical exegesis: rather than appeal to other Jewish exegetical texts in order to compose his own analysis of the book of Genesis, Philo looks to Plato, Aristotle, the Stoics and the Pythagoreans for guidance on how to interpret the infallible words of Yahweh.

42 The notion that the kosmos was 'living' is implicit in Aristotle's account of Pythagorean cosmology (see earlier), but it was made explicit in Plato's Timaeus (see esp. Ti. 3ob-d), although Plato did not commit to anthropological analogising of the World-Soul. 


\section{I3.4 Philo of Alexandria and the Pneumatic Consubstantiation}

Philo of Alexandria helps us to understand better how wise animals, such as Socrates and the Kosmos, can be thought to possess a pneumatic capacity beyond that of other individual substances in nature. Our first piece of evidence helps to understand, in particular, how 'tenor' is thought to work, but also mentions the highest species of breath, what binds bodies together 'by rational soul':

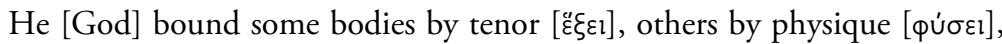

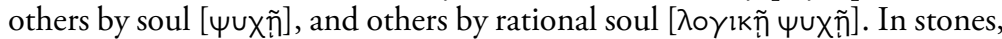
and logs which have been severed from their physical connection [sc. to the tree], he created tenor which is the strongest bond. This is breath which

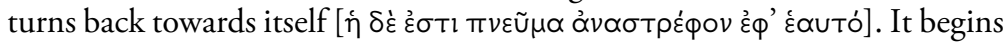
to extend itself from the centre to the extremities, and having made contact with the outer surfaces it bends back again until it returns to the same place from which it first set out. (Philo of Alexandria, God's Immutability 35-6 = Long \& Sedley 47 Q; tr. by Long \& Sedley)

'Tenor' so constructed is a kind of back-turning force that bonds material parts together into a compound, something like a magnetic polarity. It functions as a sort of circulatory system, moving around the object's interior and hence uniting it like a sort of 'glue'. ${ }^{43}$ According to Philo, 'tenor' extends to all objects, living or lifeless, including not only stones and logs, mentioned here, but also bones, 'which resemble stones', as he says in Allegories of the Laws (2.22-3 = L\&S $47 \mathrm{P}) .{ }^{44}$ Hence, objects like logs that have been separated from their natural origin for growth still possess the lowest form of breath - the same, we might wonder, could extend to, for example, severed limbs - at least until they begin to decay. Indeed, in the Questions and Answers on Genesis (2.4 = L\&S $47 \mathrm{R}$ ), which survives only in a medieval Armenian translation from Greek, Philo explains that God is said to have commanded Noah to tar the ark both on the outside and the inside (Genesis 6:I4), because all things derive their natural unity from the external and internal types of 'tenor'; the former is the corporeal type of tenor, which fixes the external boundaries of an individual human being; the latter is said to be his soul, which also circulates from the centre to the periphery rotationally. Hence, Philo appears to believe that humans - and Noah's Ark - possess two types of 'tenor', external and internal,

${ }^{43}$ The circulation metaphor is implied by the use of the term ở $\alpha \sigma \tau \rho \varepsilon \dot{\varphi} \varphi \sigma$, which is employed by Plato to refer to the circulation of blood within the veins $(T i .85 \mathrm{c})$.

${ }_{44}$ According to Diogenes Laertius $(7.138-39=\mathrm{L} \& \mathrm{~S} 47 \mathrm{O})$, breath pervades the body of an animal as 'tenor' at the point of its bones and sinews. 
corresponding to the body and the soul. ${ }^{45}$ About the highest 'rational' type of 'breath' in Philo's view, we will have to embark on an analysis of his exegetical works on Genesis, which requires us to go on a brief digression about the rise of 'exegetical' texts in the Post-Hellenistic world.

One major difference between Hellenistic and Post-Hellenistic intellectual cultures and philosophy is the formal emergence of an exegetical habit. ${ }^{46}$ Prior to the dissolution of the philosophical schools in Athens in the 8 о В В with regard to what we might consider 'wisdom-texts', ranging from Homer and the Hebrew Bible to Plato's dialogues. Within the Platonist and Stoic schools, however, works that seek to explain what meanings, concepts, themes, and systems of ethics underlie wisdom-texts become codified into recognisable genres, and thus is born what is often generally understood to be the 'commentary tradition'. This represents an expansion of a genre of scientific literature that is often considered to have originated with the writings of Aristotle on Homer, and one might refer to this sort of scientific literature as 'zetetic', after the title of a lost work that comes down to us (the Homeric Zetemata, or, more colloquially, the Homeric Questions). ${ }^{47}$ It is under the 'zetetic' genre of scientific literature that we should classify the work of Philo's that gives us his own unique point of view on 'breath' and its importance for the microcosm of the human being and the macrocosm of the ordered universe. As we saw earlier, this 'zetetic' genre tended to produce, for analysis, a single lemma of a wisdom-text and attempt to 'explain' it by appeal to lexical, philosophical, or ethical principles: $:^{48}$ Philo quotes Genesis 6:I4 ('Make yourself an ark of cypress' wood; make rooms in the ark, and cover it inside and out with pitch') and proceeds to use philosophical axioms to 'explain' what it was that God, whose word is of course perfect, said to Noah. ${ }^{49}$ This genre presupposes a surplus of meaning in the wisdom-text that goes beyond mere literal interpretation, and it exhibits a deeply embedded commitment to

45 This could create taxonomic confusions, but it may be that the text as translated from Aucher's Latin (printed in $S V F$ ) by Long and Sedley, and informed by the recent translations from the Armenian by Marcus and Mercier, is unclear.

46 On exegetical approaches in Post-Hellenistic philosophy, see Boys-Stones 20or: Chapters 3 and 6. On Philo specifically, see Boys-Stones 200I: 90-95.

47 A good recent discussion of this genre, and Aristotle's use of it, is Mayhew 2015. Of course, the posing of questions about Homer's words is anticipated by earlier intellectuals, but I am not aware that this activity constituted a genre as such.

${ }^{4}$ Here one might point to comparanda in Porphyry's Homeric Questions on the Iliad (see the recent edition of Macphail 20II) and Plutarch's Homeric Studies (Fragments I22-27 Sandbach).

49 For a fuller assessment of Philo's Platonism/Stoicism and its relationship to exegesis of the Hebrew Bible, see Engberg-Pederson 2010: 22-26. 
teleology and epistemological positivism: because God's word, transmitted through his medium Moses, is perfect, it is the exegete's responsibility to employ his capacities to unpack what it was that God meant, i.e. why he said it. ${ }^{\text {5o }}$ Implicit is the assumption that human beings are capable of obtaining knowledge (or at least justified true belief) about what God said or the prophets wrote. In this way, we now begin to see how it would be possible for Christianity, which arose in the second half of the first century CE (just after what is thought to be the date of Philo's death in $50 \mathrm{CE})$, to obtain its own unique character both (I) in the relief of pagan philosophy, which was well established, and (2) in response to philosophical-exegetical traditions already in place in Hellenic Jewish communities, such as Alexandria.

The imprimatur for approaching the formation of the macrocosm (i.e. the universe) and the microcosm (i.e. the human being) for Jewish and Christian authors was the first chapter of Genesis, which expressly presented a pneumatic cosmogony:

In the beginning, God created the heaven and the earth. And the earth was

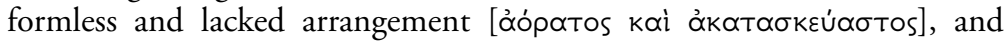
a darkness lay upon the deep, and a breath of God was borne over the

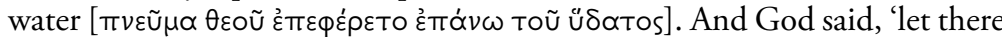
be light'. And there was light. (Genesis I:I-3, translated from the Greek version of the Septuagint $)^{5 \mathrm{~s}}$

The pneumatic cosmogony of Genesis is remarkable for its divergence from the Pythagorean tradition discussed earlier: for the Pythagoreans, it is the kosmos itself that first breathes in, whereas Genesis has God acting as a sort of prime breather in the process of differentiating the parts of the kosmos. ${ }^{52}$ A parallel passage of Genesis that Philo and the writers of the New Testament devoted a significant amount of effort to explaining and expanding is Chapter 2, verse 7: 'And God formed the man by taking clay from the earth, and breathed into his face a breath of life ( $\varepsilon \varepsilon \varepsilon \Phi \tilde{v} \sigma \eta \sigma \varepsilon v$

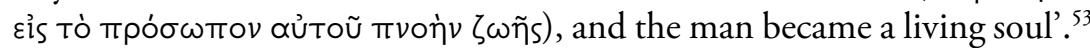
In his Allegorical Interpretation of Genesis 2 and 3, Philo devotes a long

so Cf. Barclay 1996: 169.

${ }^{51}$ For texts of the Hebrew Bible, I work from the Greek translation of the Septuagint, because it is almost certainly the text known to and used by Philo and the writers of the New Testament.

52 As contrasted with an Aristotelian notion of a prime mover. In Mesopotamian cosmology, the Enuma Elish similarly features wind as a cosmogonic force that Marduk employs in conquering Tiamat and shaping the parts of the universe (Tablets IV-V).

53 It is remarkable that Augustine sought to prove that Plato's views about the separation of the elements in Timaeus were substantially related to the pneumatic cosmogony of Genesis (De civ. D. 8.II). 
stretch of text (I.3I-42) to a multifaceted explanation of this potent statement, which links the construction of the primal human being (Adam) to God's cultivation of humankind and the activity of intellective 'inspiration' ${ }^{54}$ A sufficient analysis of Philo's exegesis would occupy far more space than I am allotted, so I will focus on the aspects of his account that help to fill out the conceptualisation of 'breath' as an intelligent sustaining force.

Philo breaks down the passage with a lexical and philological analysis, and he focuses on the meanings of key individual terms that require further explanation. One of these terms is the 'in-breathing' ( tioned by Moses:

'Breathed into' [ $\varepsilon v \varepsilon \varphi \tilde{\sigma} \sigma \eta \sigma v]$, we note, is equivalent to 'inspired' or 'be-souled'

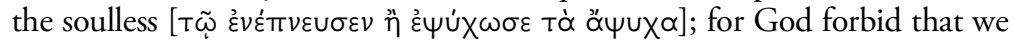
should be infected with such monstrous folly as to think that God employs for in-breathing organs such as mouth or nostrils; for God is not only not in the form of man, but belongs to no class or kind. Yet the expression clearly brings out something that accords with nature. For it implies of necessity three things: that which in-breathes, that which receives, that which is in-

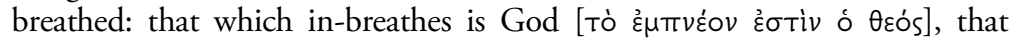
which receives is the intellect [Tò $\delta \varepsilon X$ ó $\mu \varepsilon v o v^{\prime} \delta$ voũs], that which is in-

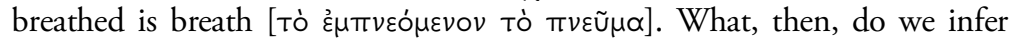
from these premises? A union [ $[\tilde{\varepsilon} v \omega \sigma i s]$ of the three comes about, as God

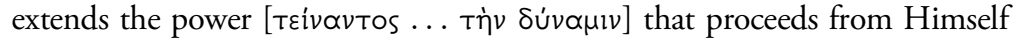
through the mediant breath till it reaches the subject. And for what purpose save that we may obtain a conception [ $\tilde{\varepsilon} v v o l \alpha]$ of Him? For how could the soul have conceived of God had He not breathed into it and mightily laid hold of it? For the human intellect [ó ờ $v \rho \omega \dot{\pi} \pi \imath$ vos voũs] would never have ventured to soar so high as to grasp the nature of God, had not God Himself drawn it up to Himself, so far as it was possible that the human intellect should be drawn up, and stamped it with the impress of the powers that are within the scope of its understanding. (Philo of Alexandria, Allegorical Interpretation of Genesis 2 and 3, I.36-38; tr. after Colson and Whittaker)

In this remarkable passage, we see the expansion of an idea of 'breath' that is already present in the Stoic constructions mentioned earlier: the idea that there is an 'active' and 'passive' element. For Philo, however, there is a tripartition - indeed, a trinity produced anthropogonically: the 'active' element is God (here functioning as something like efficient cause); the 'passive' element is the human mind (notably, not the body or the lower

$54 \mathrm{He}$ also commits extensive analysis of this lemma in his On the Creation (46.I43-40), where he explains why human beings are superior to other animals. On God as cultivator, see Questions and Answers on Genesis I.50. 
parts of the soul); and the medium of transferal of divine power is the breath itself. Interestingly, Philo follows the other Stoics in seeing breath as what constitutes a 'unity' ( $\varepsilon v \omega \sigma / \varsigma)$ or synthesis of corporeal objects relative to one another, and that this unity signifies the conferral of the divine power that 'extends' (тrivøvтos) from God to Adam, the 'earthly man'.55 The language used suggests that he is referring to the breath as 'tension'

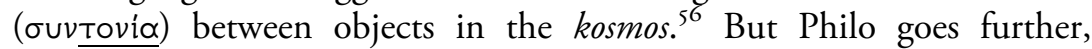
explaining that God breathed into Adam not simply for the sake of bringing him to life, like other creatures, but specifically so as to make it possible for Adam, and by extension all of his progeny, to know God; for, without the unity that is achieved through 'in-breathing', it is implied, Man would never be able to conceptualise (sc. हैvvola) God. It is implied that since Moses does not mention God 'in-breathing' into other animals, they in fact lack higher intellectual capacities and cannot know God. ${ }^{57}$

Finally, once the human 'intellect' has received the divine breath of God, how does it relate to the other parts of the soul and body? Philo explains (I.39-40) that God is not said by Moses to breathe into other parts, 'whether senses or organs of utterance and of reproduction; for these are secondary in capacity'. Hence, so Philo asks, by what were the organs of

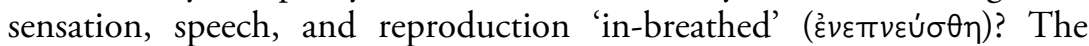
answer is that the intellect breathes into them:

For the intellect [voũs] imparts the portion of the soul that is devoid of reason a share of that which it received from God, so that the intellect was be-souled by God, but the unreasoning part by the intellect. For the intellect is, so to speak, 'God' of the unreasoning part. In like manner he does not hesitate to speak of Moses as 'a God to Pharoah' [Exod. 7.I]. For, of the things which come into being, some come into being both by God's power and through God's agency, while others come into being by God's power by not by His agency. The most excellent things were made both by God and by God's agency ... to these the intellect belongs; but the part devoid of

s5 Philo has already (I.3I-32) confusedly established that the human being who was created in this act was in fact not the 'heavenly Man' who is described as 'being made after the image of God' and 'altogether without part or lot in corruptible and terrestrial substance', but instead the 'terrestrial man' who is said to be 'compacted out of the matter scattered here and there'. One could speculate that the former exists only in the mind of God. We will later on see that Paul alters this story of two 'Adams' to make the first Adam, created by God, the 'terrestrial' Adam, and Jesus into the 'heavenly' one.

56 As Engberg-Pederson writes (2010: 20), 'what distinguishes nous and psyche - and, indeed, physis and hexis - from one another as so many forms of the material pneuma is the degree of tension (tonos) to be found in either. In nous the tension of the pneuma is so strong that it may cover the whole world and reach the stars.'

57 Cf. Philo, On the Creation 65-70. 
reason was made by God's power but not by God's agency, but by [the

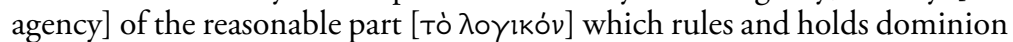
in the soul. (Philo of Alexandria, Allegorical Interpretation of Genesis 2 and 3, I.4O-4I; tr. after Colson and Whittaker)

Philo sets up a strict hierarchy of 'in-breathing', related to the animation of the many parts that make up the first human being: God breathes into the intellective part of the soul the activity of reasoning, whereas the intellective part of the soul passes on what it has of the divine pneumatic power to the lower, irrational part of the soul. The analogy is drawn: just as God is to reason, so reason is to unreason. Hence, God's capacity ${ }^{58}$ imparts breath to both the human's intellect and to the irrational part of his soul, but his agency - his direct engagement as efficient cause, so to say - only happens with the intellect. The agent or efficient cause of the lower part of the soul's animation is the rational part of the soul, the intellect who is placed over and above it as its ruler.

Hence, the major contribution to the history of cosmogonic and anthropogonic breath made by Philo is the adaptation of the Stoic metaphysics into a unique epistemological and ethical system: in his exegesis of the anthropogony in Genesis, Philo finds the grounds for differentiation of human and other animal intellective capacities, rooted in a notion of the divine gift of breath. It is a further expression of God's cosmogonic will, as paradigmatically testified by His first act as efficient cause of the universe, when His breath was borne upon the waters of the void (Gen. I:I). And, as is often the case in the ancient world, the so-called Praise of Man and his superior intellectual capacities brings in tow ethical and moral implications that reach far beyond the parameters of bare scientific explanation, such as we have seen in the cosmogony and anthropogony of the Pythagoreans. It only remains, now, to see how ancient notions of 'breath' arrive at their most powerful and influential formulation, in the writings of the New Testament.

\subsection{Consubstantiation Expanded: The New Testament and the Christian Community}

With the writings of the New Testament, we see emerge a somewhat haphazard, but nevertheless deeply informed, cosmic theology of 'breath/ spirit' ( $\pi v \varepsilon \tilde{u} \mu \alpha)$ : it shares much in common with Philo's exegesis of divine

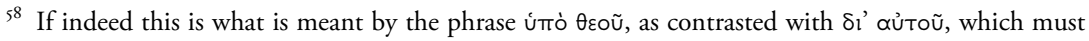
mean 'through Him', i.e. 'by God's agency'. 
'breath' across the works we have surveyed in brief, including, as we will see, a similar ideation of what I am calling 'consubstantiation', and it also demonstrates a kind of parallelism with the Stoic cosmological pneumatics described by Posidonius. It is worth checking to see whether this is the case across all the texts of the New Testament, or if it only applies in some instances. One representative version of the divine conception via a special kind of 'breath', the Holy Spirit (тò ơ $\gamma 10 v \pi v \varepsilon \tilde{\mu} \mu),{ }^{59}$ appears in the Gospel of Matthew:

Now the birth of Jesus the Messiah took place in this way. When his mother Mary had been engaged to Joseph, but before they lived together, she was

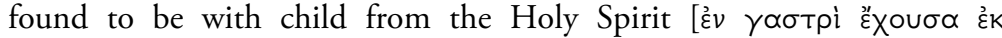
$\pi \nu \varepsilon \dot{\mu} \mu \alpha T o s \quad \alpha \gamma$ íou]. Her husband Joseph, being a righteous man and unwilling to expose her to public disgrace, planned to dismiss her quietly. But just when he resolved to do this, an angel of the Lord appeared to him in a dream and said, 'Joseph, son of David, do not be afraid to take Mary as your wife,

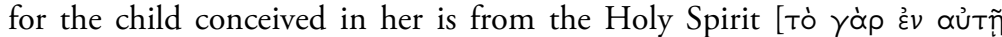

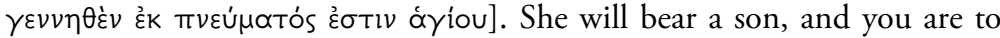
name him Jesus, for he will save his people from their sins'. (Gospel of Matthew I:I8-2I; translation in NRSV) ${ }^{60}$

In the context of the philosophical treatment of breath that we have seen earlier, this seemingly familiar passage becomes defamiliarised: the repeti-

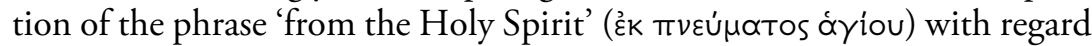
to Mary's pregnancy and Jesus' conception indicates its importance, and we are invited to wonder about the precise inflection of 'out of or 'from' $(\xi \kappa)$. It is initially unclear whether the author of the Gospel of Matthew is ascribing any agency to the Holy Spirit: it may seem that the Holy Spirit is the stuff or material out of which the impregnation and conception occurs, or that the Holy Spirit is the instrument that makes it possible for impregnation and conception. And these would be reasonable interpretations that would follow from Philo's discussion of 'breath'. But a non-philosophical alternative, perfectly acceptable in Greek, is a usage of $\dot{\varepsilon} \mathrm{k}+$ genitive that refers to parentage, and we would translate it agentially with the phrase 'by $\mathrm{X}$ ' ${ }^{61}$ Hence, a non-philosophical translation that

59 I translate 'Holy Spirit' according to convention, but it should be noted that 'spirit' and 'breath' are the same word in Greek ( $\pi \nu \varepsilon \tilde{u} \mu \alpha)$, and the term ä $\gamma 10 v \pi v \varepsilon \tilde{\mu} \alpha$ translates literally to 'holy breath'. The Gospel of Matthew has various terms that are traditionally assimilated to the Holy Spirit,

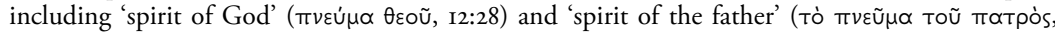
IO:20).

6o Throughout this section, I modify the NRSV only when I believe that the terms used have specific philosophical antecedents that are of relevance to this discussion (such as in the writings of Paul).

6r See Smyth I920: I688. 
retains Greek colloquy would rather be 'found to be pregnant by the Holy Spirit' or 'conceived in her by the Holy Spirit', and given the context here of Jesus' potentially dubious parentage, I would suggest this colloquial, non-philosophical usage is the best for this passage.

It is perhaps not so surprising, given the pneumatic cosmogony and anthropogony in Genesis, that the birth of Jesus would involve a similar transmission of divine breath. But, as is well known, the 'Holy Spirit' features in a variety of places in the Gospels and receives a multifaceted treatment throughout those works, sometimes in reference to certain parts of the Hebrew Bible. ${ }^{62}$ For the purpose of my argument here, I start with the Gospels before turning to Paul's writings. In the account of the Gospel of Luke I:35, an angel explains to Mary that 'the Holy Spirit will come

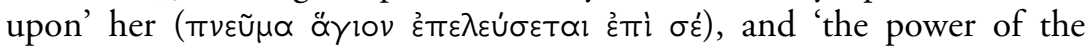

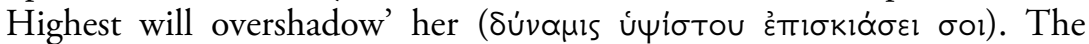
semantics here make it sound like the impregnation is a kind of physical invasion, a sort of 'climbing upon' Mary, perhaps recalling God's breath

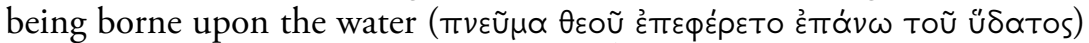
in the primal cosmogonic act of Genesis. ${ }^{63}$ Moreover, the Holy Spirit also appears to be responsible for impregnating Elisabeth with John the Baptist, if this is what is meant by referring to her as 'filled up' ( $\dot{\varepsilon} \pi \lambda \dot{\eta} \sigma \theta \eta \pi v \varepsilon \dot{\mu} \mu \alpha T o s$ óyiou) with it (Luke I:4I-43). By communicating divine information from

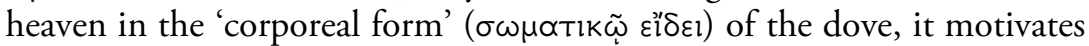
the second, higher kind of baptism (Luke 3:15-2I, 4:I; cf. the simpler version of Mark I:IO-13). ${ }^{64}$ It also motivates prophesy and inspires teaching (Luke I:67; Luke 4:I4). It itself acts as a teacher and, even, an advocate for Jesus after his death, transmitting his words posthumously (John I4:15-26 and I6:13-15). ${ }^{65}$ Finally, when Jesus dies (Luke 23:46), after darkness has fallen upon the land, Jesus calls out to His Father and screams 'into your hands I commend my spirit' (

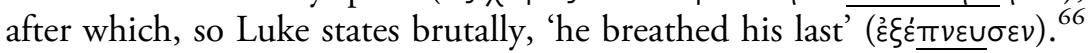
Thus, in Luke's colourful and sensitive narrative, Jesus' birth and death

62 See e.g. the citation/translation of Isaiah 6I:I at Luke 4:18.

${ }^{63}$ Gen. I:3, employing the Septuagint's translation.

${ }^{64}$ Not only does it inform Jesus that he is the son of God; it also leads Jesus into the wilderness to be tempted. The inclusion of the qualifying marker 'in corporeal shape' here indicates that the breath itself is incorporeal, contrary to Stoic assumptions. It should be remarked that Luke, also likely a Hellenic Jew from Antioch, was said by Paul to have been a physician (Col. 4:I4).

65 In the Gospel of Mark, it will act on behalf of his disciples when they are arraigned, even speaking for them on trial (Mark I3:II).

66 Luke places a certain emphasis on 'breath' through Jesus' quotation of Psalm 3I:5, which is wholly absent from the accounts of Mark (15:33-37) and Matthew (27:49-50). 
occur in parallel circumstances, with the transaction of breath between God and Man, and the settling down of shadows.

Other works of the New Testament, including the Acts of the Apostles (which presents itself as a sequel to the Gospel of Luke) ${ }^{67}$ and the writings of the Apostle Paul (especially Romans and I Corinthians), feature more elaborate pneumatic systems for early Christianity. There, we see a simple cosmological spiritualism contrasted against one more groundbreaking and radical. Speaking in Acts ( $17: 24-25)$ of the 'kosmos and everything in

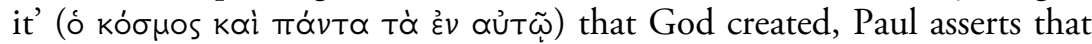
God has no need of human works because it is He himself who has given to

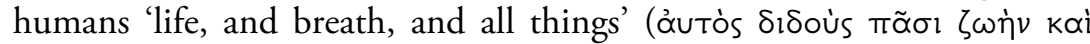

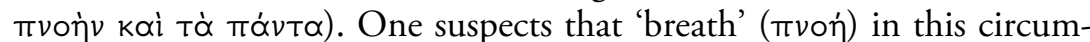
stance is not the same thing as the Holy Spirit, but simply the breath of life. Indeed, there are indications in Letter to the Ephesians that when he speaks of the kórnos, Paul refers to the world that is subject to birth and destruction, and not to the heavenly realm that is pervaded with the Holy Spirit. ${ }^{68}$ Elsewhere in Acts, the Holy Spirit becomes the primary medium for the transmission of Jesus' teachings, and even the catalyst for speaking prophesy among the disciples themselves. Importantly, there is the idea that the Holy Spirit, like Philo's divine breath, possesses its own inherent power but transmits its information through intermediary vessels, in this case the Apostles. The martyr Stephen receives the wisdom of the Holy Spirit only to have his audiences reject his word and brand him a heretic (Acts 6:3-5, $6: 8-15,6: 55-56)$; and as they stone him to death in the presence of Saul (7:58-59), he imitates Jesus when he too breathes out his final words: 'Lord

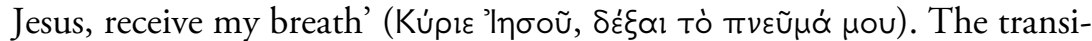
tion from Jesus to Stephen as 'recipient' serves to highlight the transitional power of the divine breath: just as Jesus receives the Holy Spirit from God the Father, so too Stephen receives it from Jesus the Son. And on and on. There is a relatively consistent pattern here: a chain of disciples is established, and the passing of divine breath on from disciple to disciple, in the form of the Holy Spirit, reveals itself as the perpetual re-enactment of the original divine activities of in-breathing of both Adam and Jesus. The Holy Spirit becomes the vehicle for the transmission of God's power from generation to generation, thus constituting and sustaining the Christian community over time. It becomes the vehicle for the Christian body of

\footnotetext{
${ }^{67}$ The narrator 'Luke' begins the Acts I:I-2 by saying, 'In the first book, Theophilius, I wrote about all that Jesus did and taught from the beginning until the day when he was taken up into heaven, after giving instructions through the Holy Spirit to the apostles whom he had chosen'.

${ }^{68}$ Eph. I:3 and 2:2. Also see Col. 2:4 and 2:20.
} 
adherents - a cosmopolitan expression of Stoic pneumatology, with the shift of focus from the universe to the human individual.

When we turn to the writings of Paul, the pneumatology starts to dovetail more strictly with its expression in the writings of Philo, the Stoics and the Pythagoreans. As Troels Engberg-Pederson has noted extensively, the work of Paul that most effectively situates his thought in a broader philosophical present is I Corinthians. ${ }^{69}$ The Holy Spirit there takes on certain powers that reflect what appears to be philosophical training, or at least familiarity, on Paul's part. For example, in I Corinthians I2, a short digression entitled 'On the Spiritual [Gifts]' (Пвpi $\tau \tilde{\omega} v \pi v \varepsilon \cup \mu \alpha \tau \imath \kappa \tilde{\omega} v),{ }^{70}$ Paul develops an elaborate description of how the Holy Spirit unifies the community under Christ:

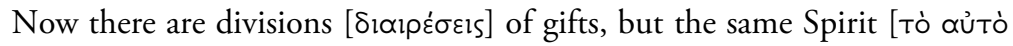
$\pi \nu \varepsilon \tilde{\mu} \mu]$; and there are divisions of services, but the same Lord [o aủtòs kúplos]; and there are divisions of activities, but it is the same God who

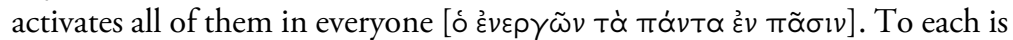

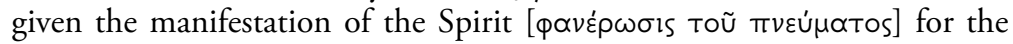
common good. To one is given through the Spirit the utterance of wisdom

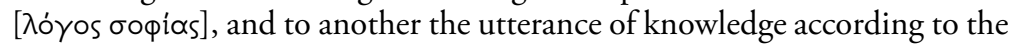

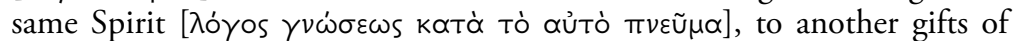
healing by the one Spirit, to another the working of miracles, to another

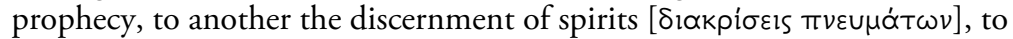
another various kinds of tongues, to another the interpretation of tongues $[\varepsilon \rho \mu \eta \nu \varepsilon i \alpha \gamma \lambda \omega \sigma \sigma \tilde{\omega} v]$. All these are activated by the one and the same Spirit

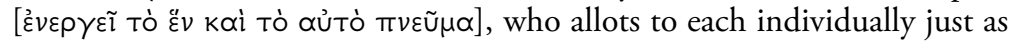
the Spirit chooses. For just as the body is one and has many members, and all the members of the body, though many, are one body, so it is with Christ. For in the one Spirit we were all baptized into one body - Jews or Greeks, slaves or free - and we were all made to drink of one Spirit. (I Corinthians I2:4-I3, translation after NRSV)

As the passage demonstrates, Paul marshals a range of concepts familiar from Hellenistic and Post-Hellenistic philosophy ('the same breath', or

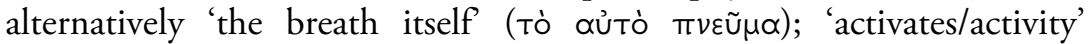
( 'the speech/reasoning of wisdom' ( $\lambda$ 'o

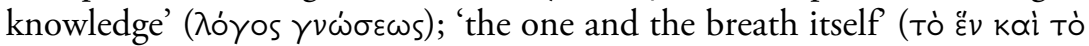
aủTò $\pi v \varepsilon \tilde{u} \mu \alpha)$ ) to make the case that the community of followers of Christ

69 Generally, see Engberg-Pederson 20I0.

70 The passage begins with these words, setting the theme. But titles of Greek philosophical and theological works have the same format: 'On X'. The digression lasts until Chapter I5. 
is like the body that has many (corporeal) members, all brought into unity by the 'one breath' that is the Holy Spirit. Hence, for Paul, the Holy Spirit not only unites all the parts of the 'body of Christ'; it also differentiates what sorts of activities each person is best suited to do, according to the will of the Holy Spirit. What, however, is the ontological status of the 'breath' that unites the Christian body, assigns each part of it its proper function, and renders the whole compound wise and capable of understanding God and his wisdom, which is otherwise 'secret and hidden'? ${ }^{71}$ In order to gain ground on this issue, we need to consider Paul's rereading of the primordial anthropogony in Genesis 2:7, which I mentioned earlier:

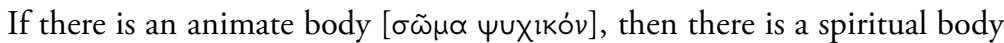

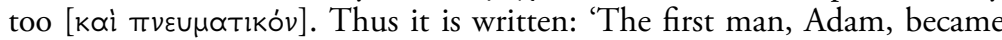

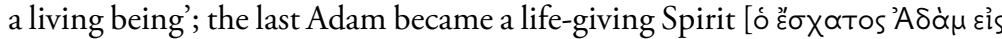
$\pi \nu \varepsilon \tilde{u} \mu \alpha \zeta \omega \circ \pi \circ \circ \tilde{v} v]$. But it is not the spiritual that is first, but the animate, and then the spiritual. The first man was from the earth, a man of dust; the second man is from heaven. As was the man of dust, so are those who are of the dust; and as is the man of heaven, so are those who are of heaven. Just as we have borne the image of the man of dust, we will also bear the image

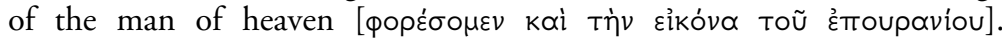
(I Corinthians 15.44-49; translation after NRSV)

Just as we saw with Philo above, Paul differentiates two sorts of 'Adams', by reference to his exegesis of Genesis 2:7. For Philo (Allegorical Interpretation of Genesis 2 and 3, I.3I-32), there is a heavenly or cosmic Adam who was 'made after the image of God' and 'altogether without part or lot in corruptible and terrestrial substance', as contrasted with the 'terrestrial Adam' who is said to be 'compacted out of the matter scattered here and there'; for Paul, the 'last' or heavenly Adam is Christ, the 'life-giving Spirit'

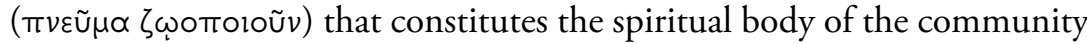
of Christians, whereas the terrestrial Adam is the figure whom God created on the sixth day, the 'man of dust'. It is true, as Engberg-Pederson has argued impressively by reference to this passage, that Paul is employing Stoic terms and concepts, reflecting his intellectual environs and reacting to Philonic exegesis. ${ }^{72}$ But that is not everything. Through the act of differentiating the 'animate' from the 'pneumatic' Christian bodies, Paul effectively appropriates the kinds of theological speculation found in the writings of Philo (and no doubt other philosophical Hellenic Jews whose works we have lost) to reject their accounts, and to highlight the status of the human being with reference to divine breath as incomplete in the

${ }^{71}$ See I Cor. 2:6-I3. $\quad{ }^{72}$ Engberg-Pederson 2010: 26-31. 
account of Moses. ${ }^{73}$ In doing so, he establishes the theological foundations of Christianity with characteristic aplomb, reconstructing it out of the scattered and even perhaps eclectic material that constituted Hellenic Jews' unique blend of Platonist metaphysics, Stoic physics and Jewish biblical exegesis. Consubstantiation within the Christian community now goes beyond Philo's Stoic trinity of 'God, Adam, Breath', or the Gospels' 'Father, Son, Holy Spirit': it reaches across the entire body of Christ's followers, from the death and rebirth of the 'last Adam' until the final return after the Judgement.

\subsection{Conclusions}

In tracing a particular genealogy of spiritual cosmologies from the early Pythagoreans of the fifth century в С to the writers of the New Testament in the mid to late first century $\mathrm{CE}$, we have examined how various notions of 'breath' ( $\pi v \varepsilon \tilde{u} \mu \alpha)$ have informed the description of the ordered world

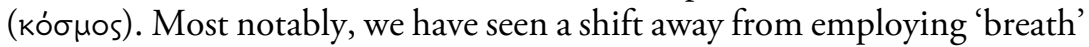
as a biomorphic instrument for explanation of how individuals obtain proper order and differentiation in the thought of the Pythagoreans and Stoics to a prime candidate for supplementing incomplete understandings of human creation and salvation in the writings of Philo and the authors of the New Testament. While conceptualisations of the kosmos have remained static, for the most part, the notion of 'breath' has expanded and become more comprehensive as we have proceeded through the Hellenistic to the Post-Hellenistic world. Despite these important connections, no revolution in spiritual cosmology in the Greco-Roman world can be said to be greater than what occurred among the Early Christians. Speaking to the apostle Philip in the Gospel of John, Jesus promises to intercede on behalf of his followers and request from His Father an intercessor, to act on their behalf:

If you love me, you will keep my commandments. And I will ask the Father, and He will give you another advocate, in order that I might be with you for

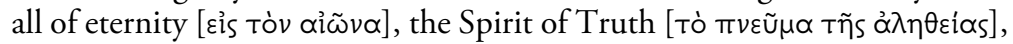

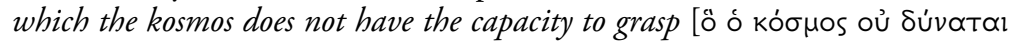
$\lambda \alpha \beta \varepsilon \tau v]$, because it does not contemplate it and it does not know it [öтl oủ

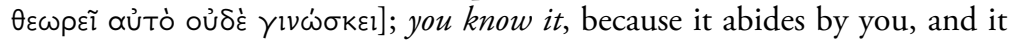

73 Cf. Boys-Stones 200I: 165-67. For Paul's account of the restoration of the kosmos through Christ as

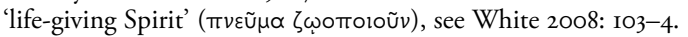




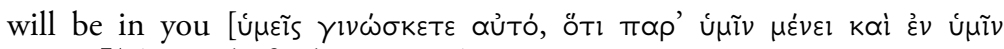

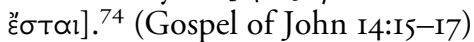

Here we see the most compelling evidence of the Christian rejection of the spiritual kosmos of ancient Greek philosophy for an alternative spiritualism. Whereas the Pythagorean kosmos obtained its birth from an act of breathing in the external void, and the Stoic kosmos persisted uniquely through the reciprocal activities of respiration, the kosmos as described by John is blind and deaf to the Spirit of Truth, neither recognising it nor contemplating it. This is neither the biomorphic kosmos of the Pythagoreans, nor the intelligent kosmos of the Stoics: this kosmos is wholly bereft of the Spirit of Truth, which functions here as the eternal guarantor of co-presence with Jesus. Cosmic and human pneumatic analogies have been rejected and replaced with a new sense of the Spirit of Truth (тò $\pi v \varepsilon \tilde{u} \mu \alpha$ тñ $\alpha^{3} \lambda \eta \theta \varepsilon i \alpha s$ ), which the kosmos is unable to admit due to its insufficiency. Hence, in the Gospel of John, we witness the ultimate rejection of the pagan spiritual cosmologies - with all their metaphysical and physical entailments - of the Pythagoreans, Stoics, and Hellenic Jews, and their replacement with the eternal community of Christian believers, unified through the Holy Spirit, and not limited by this kosmos.

To be sure, this rejection of pagan spiritual cosmologies is not a total abandonment of the principle of kosmos. As Engberg-Pederson has argued in speaking about Paul's spiritualism, 'pneuma ... is an entity that is primarily connected with being in the group. It highlights a certain stable state of the believer. ${ }^{75}$ As far as Paul's ethics of belief go, we should note that, for Engberg-Pederson, $\pi v \varepsilon \tilde{\mu} \mu \alpha$ 'is stated to be responsible for certain states of mind, namely mental attitudes, in fact for nothing other than the virtues in the Greek philosophical tradition' ${ }^{76}$ This represents a notable shift away from what we saw in the Stoics and Philo, who attributed to 'breath' notions of intelligence and discriminatory capacity, but did not take the further step of advancing upon moral psychology. Moreover, because of its importance for community-building among the Christians, the Holy Spirit, or the Spirit of Truth, possesses eschatological significance: after all, it is the guarantee of (among other things) a post-Apocalyptic community of believers that makes Christianity attractive within the competitive intellectual and religious economy of the early Roman

\footnotetext{
${ }_{74}$ Translation mine; italics mine, for emphasis. $\quad{ }^{75}$ Engberg-Pederson 2000: 158.

${ }^{76}$ Ibid., I6o, by reference to the virtues of love, joy, peacefulness, magnanimity, kindness, goodness, loyalty, mildness and self-control (Galatians 5: 22-23).
} 
Empire. ${ }^{77}$ In this light, consider the prophetic vision offered to John of Patmos - effected by the Holy Spirit (Revelation I:IO, 21:IO) - of the promised invitation to the city of New Jerusalem:

The Spirit and the bride say, 'Come'.

And let everyone who hears say, 'Come'.

We are meant to understand that the Holy Spirit, wed to its 'bride', the city of New Jerusalem (Revelation 21:2, 2r:9), calls those who have heeded the words of John's book. All this is an expression of the heaven and earth that are revealed after the final Judgement, New Heaven and New Earth (Revelation 2r:I), where there will be no more darkness of night, banished by the light that is God diffused throughout New Jerusalem (Revelation 22:5) - a second banishment of the darkness of the void from Genesis. This place is what John of Patmos calls the 'holy city' ( $\dot{\eta} \pi \lambda_{1 S} \alpha \dot{\gamma}$ in): it is constituted through the binding of the Holy Spirit to the bride and presented as a place of unity for those who have heeded the words of prophesy. In the end, it is the Christian kosmopolis, heralded by the Holy Spirit, that manifests a new vision of the kosmos of Greek philosophy.

77 For the usefulness of 'wisdom' as a point of comparison among Hellenistic, Jewish and Christian intellectual communities, see Alexander 200I: I22-26. 